\title{
A Review of "The Indo-Pacific Axis: Peace and Prosperity or Conflict?" by Satish Chandra and Baladas Ghoshal
}

\section{Chetan Rana}

DOI: https://doi.org/10.22151/politikon.46.4 Chetan Rana holds a Masters in Politics (with specialisation in International Studies) from School of International Studies, Jawaharlal Nehru University, New Delhi. He is also a research intern with Dr. Manali Kumar. His interests include Security studies, India's foreign policy, politics in South Asia, and South East Asia. E-mail: chetan.rana96@gmail.com.

\section{Keywords}

Indo-Pacific, China, United States, ASEAN, India, Peace, Japan, Rebalancing, South China Sea, Australia 
The term Indo-Pacific emerged only in the 2000s and as a single, continuous security complex only in this decade. The emergence of this new strategic reality is a reflection of the rise of Asia, in particular of China, and the relative decline of the United States (Panda 2018, 119-20). Swaran Singh (2018, 142-143), while addressing the relationship between peace and prosperity, has claimed that China is utilising the idea of peace emerging from a prosperous region (an occidental idea) to legitimise its actions in the region. The United States used the same idea while building its hegemony. The book, "The Indo-Pacific Axis: Peace and Prosperity or Conflict?," acknowledges this shift and explores the potential for peace as well as conflict in the region. The book is an edited compilation of thirteen papers by thirteen different scholars and bureaucrats. It sets out to cover diverse issues in the Indo-Pacific with a special focus on India's location within the region. The book succeeds in exploring (i) the emergence and varying definitions of the Indo-Pacific, (ii) the complex economic and security relations amongst the states, and (iii) the potential role India can play. Yet there are key issues that have not been adequately addressed in the book.

\section{A Region Reimagined}

One of the fundamental features of the Indo-Pacific construct is its primary maritime character. It is seen as the "confluence of two seas." China has been reluctant to accept this expansion of identity away from the earlier Asia-Pacific construct. Rajiv Bhatia (2018, 36) defines the Indo-Pacific region as the amalgamation of the Indian Ocean and the Asia-Pacific regions where China's primacy dilutes as opposed to Asia-Pacific where China was considered the primary power. This depicts that the former nomenclature is used in order to dilute the geopolitical and even social primacy attributed to China with the latter nomenclature with a greater emphasis on India's inclusion as a stakeholder in the region. Ghoshal has identified economic primacy of the region as the driving force behind the shift. It has been argued that the rise of China and its hegemonic aspirations were the main reasons for the US's re-engagement in the region through a 'pivot to Asia' or 'rebalancing' policy under the Obama regime, for example in the South China Sea (Vijayalakshmi 2018, 86-90).

The book successfully captures perspectives of the major actors that are the United States (Vijayalakshmi 2018, 79-108; Samaddar 2018, 109-118), China (Singh 2018, 141-154), India (Ghoshal 2018, 9-22; Wadhwa 2018, 23-26; Bhatia 2018, 33-48), Australia (Brewster 2018, 4958), Japan (Panda 2018, 119-140), and Indonesia (Sundararaman 2018, 177-196). The variety of scholarship and perspectives bring out the prevalent ambiguity over the definition of the limits of the region, the prioritisation of different threats and concerns in the region, and the different internal and external drivers of foreign policies. 
The United States and its allies and many non-alliance partners are driven to cooperate and preserve the existing rules-based order. This has manifested in clear condemnation of China's policies in the South China sea, especially the land reclamation and militarisation of the Spratly Islands and the A2/AD strategy (strategy to prevent an adversary from traversing an area). Yet, the emergence of this new great power rivalry is starkly different from the US-Soviet Cold War. This new rivalry is characterised by multipolarity, a primarily maritime rather than continental playing field, the emergence of non-traditional threats, and comprehensive economic interdependence (Samaddar 2018, 112-113). The United States has shifted its policy from a "San Francisco Alliance System" to a "Pivot to Asia," and the majority of scholars, along with US policymakers, have identified India as the "lynchpin" in the strategy. The need for realignment, both internal and external, is best captured in Japan.

“Ever since adopting the Peace Constitution, Article 9 has remained the cornerstone of Japan's defensive posture. The changing geo-political situation in its neighbourhood has been compelling Japan to revisit this option. Given the strong pacifist sentiment in Japan, abrogating article 9 is not easy. What the Abe government is doing, therefore, is to dilute the spirit of the article slowly but incrementally by reinterpreting it in order to realise its objective without tampering with the constitution" (Panda 2018, 121).

\section{Multiple Players and Multiple Motives}

The need to invite contributors from varying expertise for the book encapsulates the layered and dynamic nature of relations in the region. Unlike the bipolar politics of the Cold War, the conflict in the Indo-Pacific demands more than just binary perspectives of bandwagoning and balancing. China is the biggest trading partner of almost all the countries in the region whereas the United States is still traditionally the strongest security provider. States such as Japan and Australia have been a part of the US's security alliances; however, due to India's historical policy of Non-alignment and Indonesia's Bebas dan Aktif (Independent and active), they will always be reluctant to compromise on their strategic autonomy. Due to the immediate threat of an aggressive China and the stark asymmetrical capacity, countries in the region have repeatedly emphasised the creation of an inclusive Indo-Pacific as a means to dissipate China's concern of a containment policy against it in the region.

Three categories of conflicts have been identified which capture the wide array of problems in the region, both traditional and non-traditional (piracy, terrorism, and climate change) threats. While China is at direct loggerheads with other states in traditional and neo-traditional conflicts, it is non-traditional threats (like natural disasters) that Asian states seek to collaborate with China. Collaboration (against piracy and for disaster management) and economic integration (such as the Regional Comprehensive Economic Partnership (RCEP) are important policy tools in the hedging baskets available to the states in the region. 


\section{India: Balancer or Bridge}

India has gained centrality in the politics and strategies of the Indo-Pacific players. India has been labelled as the 'lynchpin' of the US's strategy (Vijayalakshmi 2018, 90-91). It recognises the Indian Ocean as its primary area of interest, and the Pacific (including the South China Sea) as its secondary area of interest. It has stakes in the region as India's trade is vulnerable to various chokepoints and the South China sea is a part of its energy diversification plans. Furthermore, a hegemon for a neighbour is not desirable. However, there are still doubts about India's stance on its role as a lynchpin (Samaddar 2018, 117). On the one hand, India will not act directly against China. On the other hand, India has been one of the loudest voices in creating an inclusive IndoPacific region. It is argued that India can best achieve its national interests by maintaining strategic autonomy. It has also sought to keep the US at an arm's length by emphasising the centrality of Association of South East Asian Nations (ASEAN) and other multilateral arrangements in the region. Swaran Singh $(2018,153-154)$ suggests that Indian can aim to be a bridge. It can utilise its relations and proximity with the United States and China as a niche.

\section{Comprehensive but Incomplete}

The book has striven to provide a comprehensive assessment of the issues that it has sought to address. Yet there are key elements in the politics of the Indo-Pacific that have either gone amiss or have been inadequately dealt with. It only briefly mentions arrangements such as RCEP (in competition with US's Trans-Pacific Partnership (TPP)) and projects on regional connectivity. The politics in the region are very dynamic, and for a book published in 2018, it has failed to update the status on RCEP, TPP, Belt and Road Initiative (BRI), Maritime Silk Route (MSR), the Quad, etc. These projects will fundamentally shape the emerging strategic coalitions and trade relations in the region.

Even though the book delivers in providing perspectives of various stakeholders, it does not address the centrality of ASEAN and its institutional arrangements. Most authors have only fleetingly mentioned the roles of the regional institutions and have failed to juxtapose the role of these institutions with the foreign policies of the states. Further, the roles of many littoral states and ASEAN states are not represented. Cambodia and Laos have paralysed recent ASEAN conferences as they are securing China's interests. Similarly, many littoral states are leasing out islands for military bases. These events greatly influence the course of politics in the region. While the approach of stakeholder-wide discussion brings light on a great many details, it fails to juxtapose different strategies simultaneously in operation in the region.

In conclusion, the book is a compact guide to the unfolding politics of the Indo-Pacific. Most importantly, it elucidates the myriad discourses that are operating in the region without 
making unfalsifiable predictions, and therefore preventing itself from creating an unbalanced narrative. It engages with the security as well as the political and economic considerations. Both the shortcomings and the achievements of the book reflect the complex nature of interests and the relations in the region.

\section{References}

Bhatia, Rajiv. 2018. "Indo-Pacific Region: An Indian Perspective" in The Indo-Pacific Axis: Peace and Prosperity or Conflict?, edited by Satish Chandra and Baladas Ghoshal, 33-48. New Delhi: Manohar.

Brewster, David. 2018. "India and Australia: Creating New Strategic Geometries in the IndoPacific" in The Indo-Pacific Axis: Peace and Prosperity or Conflict?, edited by Satish Chandra and Baladas Ghoshal, 119-141. New Delhi: Manohar.

Ghoshal, Baladas. 2018. "Introduction" in The Indo-Pacific Axis: Peace and Prosperity or Conflict?, edited by Satish Chandra and Baladas Ghoshal, 9-22. New Delhi: Manohar.

Panda, Rajaram. 2018. "Japan and the Changing Geopolitics of the Indian Ocean: An Indian Perspective" in The Indo-Pacific Axis: Peace and Prosperity or Conflict?, edited by Satish Chandra and Baladas Ghoshal, 119-140. New Delhi: Manohar.

Samaddar, Sujeet. 2018. "The US Pivot to Asia: Implications for the Indo-Pacific" in The IndoPacific Axis: Peace and Prosperity or Conflict?, edited by Satish Chandra and Baladas Ghoshal, 109-118. New Delhi: Manohar.

Singh, Swaran. 2018. "Locating China in the Evolving Discourses on the Indo-Pacific Geopolitics" in The Indo-Pacific Axis: Peace and Prosperity or Conflict?, edited by Satish Chandra and Baladas Ghoshal, 141-154. New Delhi: Manohar.

Sundararaman, Shankari. 2018. "Understanding the Indo-Pacific: Why Indonesia will be Critical?" in The Indo-Pacific Axis: Peace and Prosperity or Conflict?, edited by Satish Chandra and Baladas Ghoshal, 177-196 . New Delhi: Manohar.

Vijayalakshmi, K.P.. 2018. "The US and Indian Ocean Region: Implications in India" in The IndoPacific Axis: Peace and Prosperity or Conflict?, edited by Satish Chandra and Baladas Ghoshal, 79-108. New Delhi: Manohar.

Wadhwa, Anjil. 2018. "India's Approach to the Indo-Pacific" in The Indo-Pacific Axis: Peace and Prosperity or Conflict?, edited by Satish Chandra and Baladas Ghoshal, 23-26. New Delhi: Manohar. 